\title{
sciendo
}

\section{The Looming Central and Eastern European Real Convergence Club. Do Implicit Tax Rates Play a Part?}

\author{
Liliana E. Donath ${ }^{1}$, Petru-Ovidiu Mura ${ }^{2}$
}

\begin{abstract}
The paper investigates whether there is a convergence club stance for the Visegrad countries plus Romania and Bulgaria and the part played, in this process, by the implicit tax rates on labour and consumption, respectively. For the purpose of the research, the GDP per capita, productivity and unemployment are used as convergence indicators and dependent variables. The dataset covers the 1995-2016 timeframe and the analysis is based on a panel-model approach. The main results show that the implicit tax on labour has no significant effect on the convergence indicators while the implicit rates on consumption are statistically significant with negative influence. The interpretation of results is made considering a set of control and robustness variables where policy lessons derive from. The conclusion reflects on the policy lessons that can serve to accomplish the convergence club within selected CEE countries: Bulgaria, the Czech Republic, Hungary, Poland, Slovakia and Romania.
\end{abstract}

\section{Keywords}

Convergence Club, Implicit Tax Rate on Labour, Implicit Tax Rate on Consumption, CEE Countries, Real Indicators

\section{Introduction}

Real convergence is an aggregate concept that emphasises the causal and functional correlations within the regional economy, conferring development an endogenous and contextual character. Moreover, the real convergence indicators focus on generating results rather than on targets as in the case of nominal convergence indicators. The embedded information is consistent with the economic and social policies, showing the causal, functional and structural evolutions in the real economy and, last but not least, is in line with the European common budgetary policy.

\footnotetext{
${ }^{1}$ West University of Timisoara, Strada Johann Heinrich Pestalozzi 16, Timisoara 300115, Romania. E-mail: liliana.donath@e-uvt.ro.

${ }^{2}$ West University of Timisoara, Strada Johann Heinrich Pestalozzi 16, Timisoara 300115, Romania. E-mail: petru.mura@e-uvt.ro.
} 
As a first step, regional integration sets the foundation of a larger attempt to join the group of developed countries in the euro zone. If the selected CEE countries (i.e. Bulgaria, the Czech Republic, Hungary, Poland, Romania and Slovakia) are able to narrow economic and social differentials, then a convergence club occurs that can contribute to the EU economic and social cohesion at large. It would allow a better resilience to exogenous shocks, provided that a convergence club regards a group of countries with similar economic tendencies (Simionescu, 2015).

On the other hand, the modern tax systems are rather complex, and besides their financial meaning, they mirror the economic stance of a country, the level of the tax base and the subtle political compromises that back the tax laws. When economists analyse the way taxes impact on the economy, inevitably a simplified and comprehensive model is adopted to capture the net effects of the numerous provisions of the tax laws. Therefore, the study relies on the endogenous growth models in which labour and consumption tax policies impact growth via human capital as opposed to the neoclassical approach in which fiscal policy is neutral on the long run.

The hypothesis of the paper is that given the sustained growth of the selected CEE countries and their other similarities, there is a convergence club stance that may confer this group of countries a real competitive advantage. Subsequently, the paper questions whether the implicit tax rates on labour and on consumption influence the selected real convergence indicators and may serve as cohesion tools.

The paper tracks the business cycle and, from the larger set of real convergence indicators, the GDP per capita, the labour productivity and unemployment rate, respectively, are considered for the purpose of the analyses. Since capital, as tax base, is rather scarce in these countries, the implicit tax rate on capital was not taken into account, while the implicit tax rates on labour and consumption seem inclusive enough to show the impact of taxation on the convergence process. The dataset covers the 1995-2016 timeframe and the analysis is based on a panel-model approach referring to the Visegrad countries plus Romania and Bulgaria. For the purpose of the paper, a panel data model was chosen because it allows a better control for individual heterogeneity, concentrates more informative data, more variability, less collinearity among the variables and more efficiency.

The paper is an empirical contribution to the existing literature by extending previous analyses to a larger group of countries and includes taxation as a possibly relevant tool in the convergence process.

The paper proceeds as follows: Section II Literature review, Section III Tracking selected real convergence indicators, Section IV Methodology and data, Section V Results. The remainder of the paper is dedicated to Conclusions and policy lessons.

\section{Literature review}

The cohesion of the EU member states has raised intense debates over the years. The issue has become even more important since, despite the efforts to narrow the economic and social gap, it seems that real convergence between groups of countries is far from being completed. 
The issue of convergence has been debated in literature mainly from a methodological perspective in order to depict the best models for the analyses (Ceylan et al., 2016). Real convergence is generally approached either by $\beta$-convergence or $\sigma$-convergence. $\beta$-convergence means that low income economies grow faster than higher-income economies, measured in GDP per capita in PPS, while $\sigma$-convergence considers narrowing the dispersion of income levels across economies (Baumol, 1986; Barro et al., 1992; Workie, 2004). From the perspective of the present analysis, $\beta$-convergence better reflects convergence through sustainable growth while $\sigma$-convergence derives from the former.

According to the standard neoclassical theory, developing countries can benefit from joining advanced countries, the entire process being activated by the liberalization of markets (Martín et al., 2001), but literature mainly discusses the convergence of the euro zone countries, seldom extending the debate on the CEE group of countries. Later, in the late 1990s and early 2000s, the prospect of additional CEE countries joining the EU gave another insight to this issue by including other "deep" determinants in the analysis, i.e. geography, the quality of institutions, economic openness etc. (Rodrick, 2002).

Undoubtedly, the GDP per capita is considered the most widely used indicator of convergence but, as statistics show, it becomes more relevant within a group of countries that, according to their similarities create a "convergence club" (Mlynarzewska-Borowiec, 2018). Literature also discusses extensively the role of productivity in the convergence process which, for accuracy, requires a simultaneous analysis for all countries involved (Inklaar et al., 2016). The cohesion issue has become of great concern for CEE countries that endeavour to find common grounds to overcome their laggard stance in the EU and where the need to converge is more apparent (Jovančević et al., 2015). In the same time, based on the latest developments, it can be argued that these countries have great potential of growth, individually and as a group, relying on internal economic and human resources and supported by the EU cohesion funds. Nevertheless, the integration process isn't smooth, since other endogenous variables related to historical, socio-economic and political determinants have a significant impact on integration. In addition, the liberalization and the economic gap also lead to negative aspects (i.e. brain drain, the proliferation of oligopolistic tendencies, lack of coherent economic integration strategies and special concentration) that acted as barriers and hindering cohesion (Zdražil et al., 2016). According to literature (Sorić, 2016) there isn't a large consensus concerning the optimal methodology to measuring convergence, each presenting a range of flaws.

Further down the line, taxation is widely discussed in literature, under its typology and impact at macro and microeconomic levels. Lee et al. (2005) test the impact of the tax structure and suggest that the effects are less clear for individual income, but relevant for corporations. Among the most used indicators to measure the actual direct and indirect tax burden are the implicit tax rates (ITR), that were defined, for the first time, by the EU Commission in the 2005 edition of Structures of the taxation systems in the European Union: 1995-2004, Report COM (2006) 3201, as measuring the average effective tax burden on the different types of income or activity in the economy (i.e. labour, consumption and capital). The ITR on labour is generally defined as the sum of all direct and indirect taxes and social contributions of employers and employees alike 
levied on wages and salaries, divided by the total compensation of employees working in the economic territory (Heijmans et al., 2004). The homogeneity and the consistency of this approach were improved following the harmonized data provided by ESA 95 standard. Nevertheless, this improvement is entirely effective in analyses only when the specificities of the national economic legislations are ignored and the same denominator is considered for all countries. Therefore, the validity of this formula is given by the fact that the combined effects of statutory tax rates, deductibility and tax credit are included alongside the structure of various types of income. To be noticed, though, that besides supporting the identification of a vast number of taxation determinants, the formula has several shortcomings in depicting the trends when a complete and accurate identification of determinants is not possible. Moreover, time inconsistency may also occur because of tax payment synchronisation gap and the impact of business cycle.

There have been extensive debates concerning the manner in which the tax burden has been proxied in macroeconomic studies (either as tax rate or tax wedge), but conclusions show that though they considerably differ, the correlation is high (de Haan et al., 2003). The ITR on labour is regarded as an incentive towards work and highly related to employment and working hours, mainly in the early and late stages of income life cycle, though the issue is treated separately according to gender, age and family responsibilities (Blundell, 2014). The impact of taxes on wages and unemployment depend on how wages are set, as well as welfare and unemployment benefits. Indeed, a key channel through which taxes affect unemployment is the effective replacement rate. It seems that effective tax rates on labour are rooted in welfare and unemployment benefits that are withdrawn when employment is resumed. Any changes in the tax structure can cut unemployment if they shift the tax burden to the unemployed, thereby reducing the effective replacement rate; but it depends crucially on whether the unemployed share the higher tax burden or not (Bovenberg, 2003). On the other hand, the ITR on consumption is defined as the total taxes on consumption divided by the final consumption expenditures of private households. It touches the prices and therefore the level of consumption. It is mostly regarded as a regressive tax rate that marginally produces a higher burden on lower income. Nevertheless, from the tax administration point of view it is considered as effective since lower collecting costs are involved. Therefore, it is often seen as a major source of public revenue, mainly in developing countries where direct tax revenues are lower. Though they indirectly impact on income, indirect taxation lowers the disposable income for investments and, consequently, erodes sustainable growth, based on productivity rather than on consumption. The ITRs, per se, are also studied in the context of globalization; evidence shows an increase of the ITR on labour in developed countries and a decrease in developing ones, a considerable number of the latter levying flat tax rates. On the other hand, a decrease of the ITR on consumption is noticeable in developed countries, as well as in the selected CEE countries in response to globalization. Nevertheless, it cannot be considered as a general conclusion since the analyses should be complemented with the characteristics of political regimes (Onaran et al., 2010). 


\section{Tracking selected real convergence indicators}

The evolution of the GDP, that stands for the development of the business cycle (Figure 1) shows that the considered CEE countries (i.e. the Czech Republic, Hungary, Poland, Slovakia, Romania and Bulgaria) started to grow significantly, following the same track after 2000. Nevertheless, a more sustainable trend is noticeable for Poland, which did not record the same severe down slope in 2009 as the rest of the countries. After the crises, all six economies were stabilised, growing at similar paces, above the average EU 28 growth rate of $2.3 \%$. This trend confirms the $\beta$-convergence theory and that, as a group, the CEE countries may catch up with the rest of the developed EU countries. The lack of pre-crises convergence can be mainly explained by the lack of supportive incentives for innovation and low productivity.

Figure 1: The evolution of the GDP in selected CEE countries (\%)

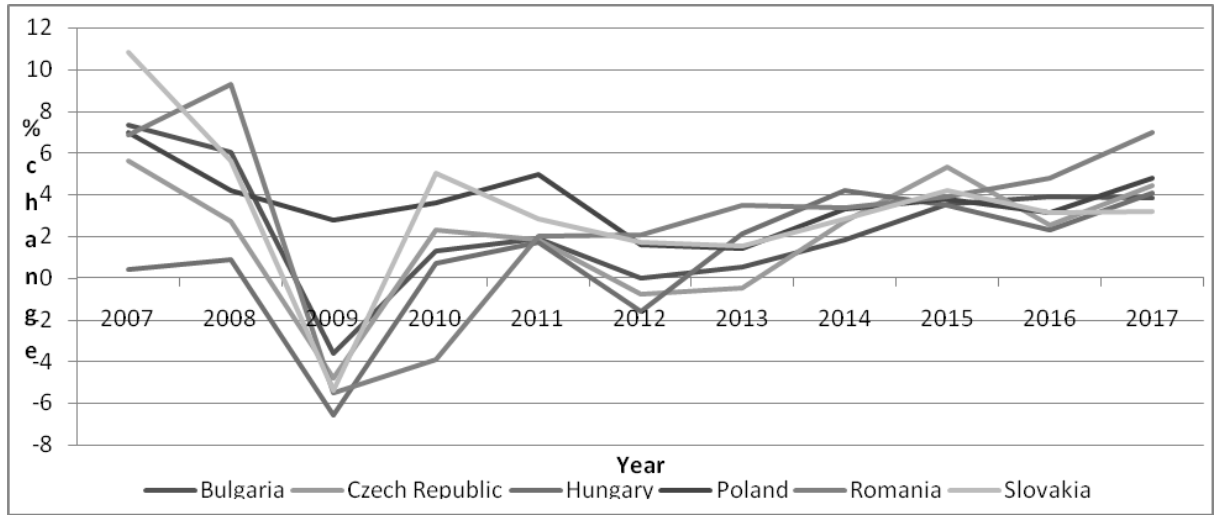

Source: Eurostat (2018)

Complementarily, the GDP per capita (Figure 2) shows a higher convergence for the Visegrad countries, Romania and Bulgaria lagging behind, since other determinants become prevalent such as labour productivity, the quality of institutional governance and demography. A lower ranking of GDP per capita is due to a mix of factors, i.e. ineffectiveness of governance, the inadequate regulatory environment, the size of informal economy.

The evolution of the GDP per capita can be related to a set of variables, i.e. Gross capital formation, Exports and FDI (Figure 3). It can be argued that the entire group of countries are recording improvements in exports (with an outstanding position for the Czech Republic, Slovakia and Hungary). The group exhibits a rather homogenous gross capital formation trend, but differentiations in FDI as \% GDP, Hungary and Bulgaria leading. 
Figure 2: GDP per capita

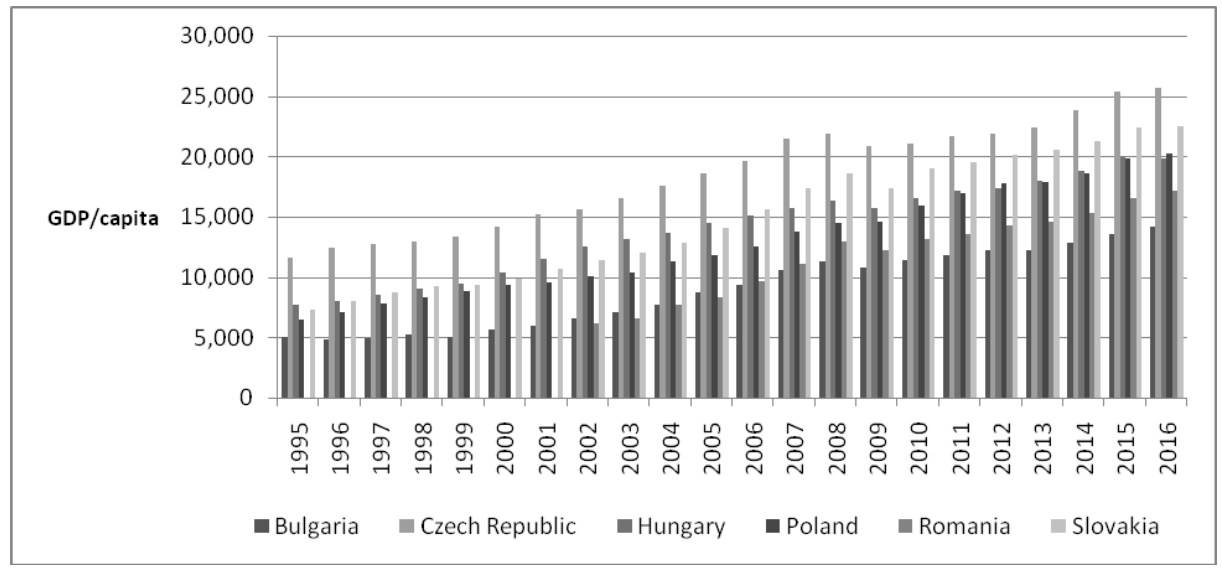

Source: Eurostat (2018)

Figure 3: Gross capital formation ( \% GDP), FDI ( \% GDP), Exports ( \% GDP)

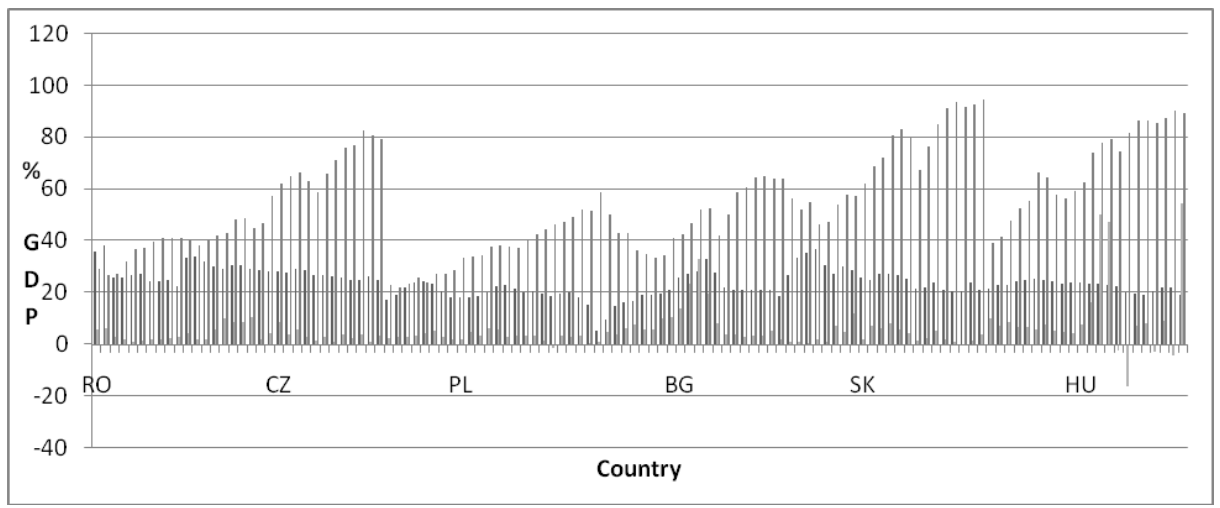

Source: Eurostat (2018)

Labour productivity is a main trigger of convergence and heavily relies on the quality of labour as an outcome of education (Figure 4). As statistics show, in Slovakia and Hungary there is a better correlation between the educated labour force (upper secondary and tertiary) and labour productivity. It means that spending on education is more efficient, supporting productivity transfer towards businesses. In Slovakia the quality of education is reflected in the increased productivity (highest effectiveness), in Hungary the gap between these indicators is narrow, while in the Czech Republic, Poland and Romania although productivity does not fully reflect the investment in labour force, the situation is rapidly improving, whilst in Bulgaria the gap is still considerable. 
Figure 4: Labour productivity and education

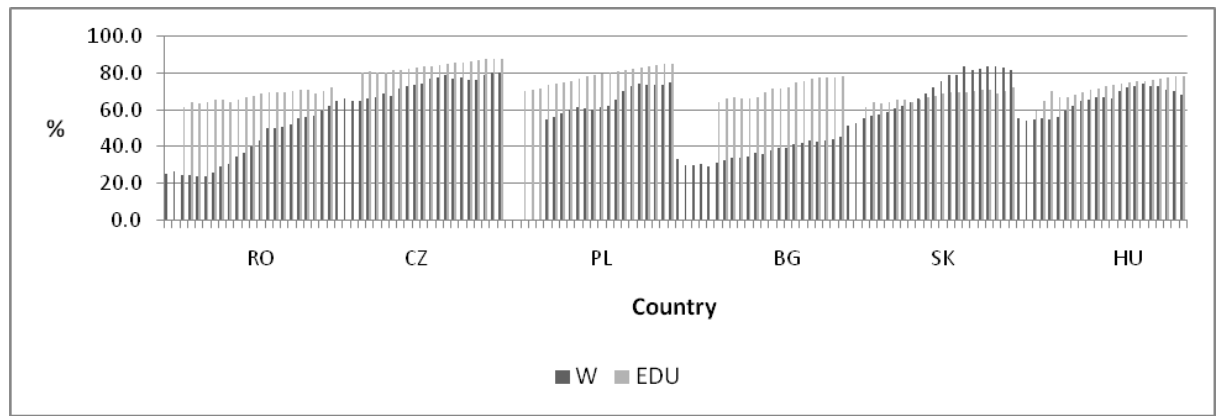

Source: Eurostat (2018)

The unemployment rate (Figure 5) remains higher in Slovakia and Bulgaria with lower levels in the Czech Republic, Hungary and Romania. The unemployment stance can be explained, largo sensu, by the rigidities in the labour market that include a high degree of employment protection and wage bargaining systems that are not supportive of flexible wage adjustments. Nevertheless, unemployment is a more complex issue that needs detailed argumentation in the context of each country including considerations on the welfare system and brain drain.

Figure 5: Unemployment rate in selected CEE countries (\%)

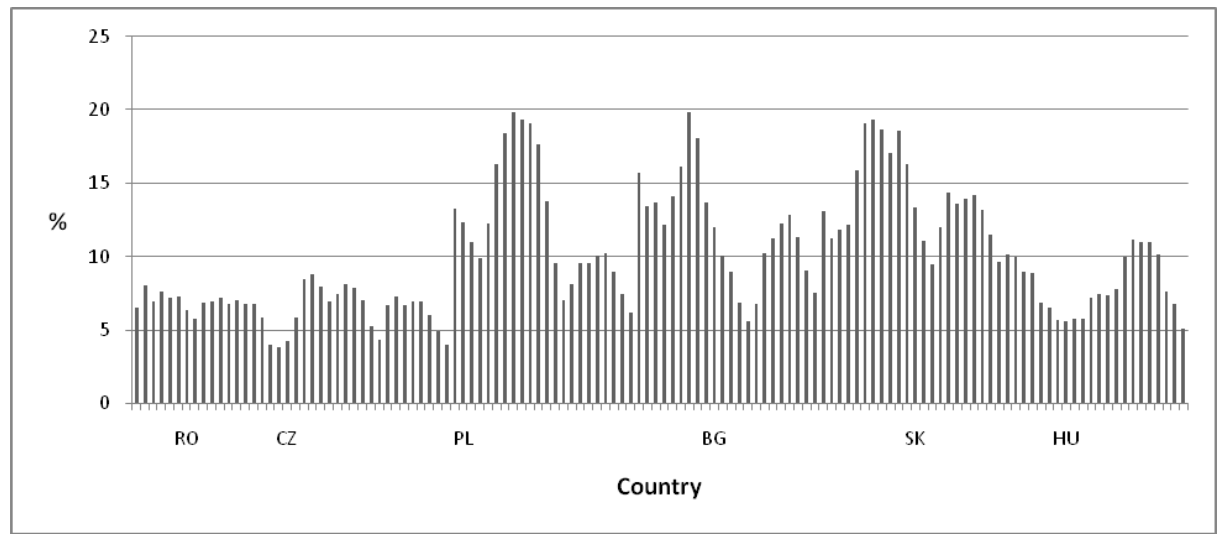

Source: Eurostat (2018)

The ITR on labour and the ITR on consumption are described in Figure 6. The evolution, consistent with literature, shows that the ITR on labour are higher than the ITR on consumption in the entire group of countries, reflecting consumption driven economies. The highest ITR on labour is in Hungary and the Czech Republic and lowest in Bulgaria; meanwhile the ITR on consumption are more harmonised, following the EU trend. 
Figure 6: ITR on labour and on consumption (\%)

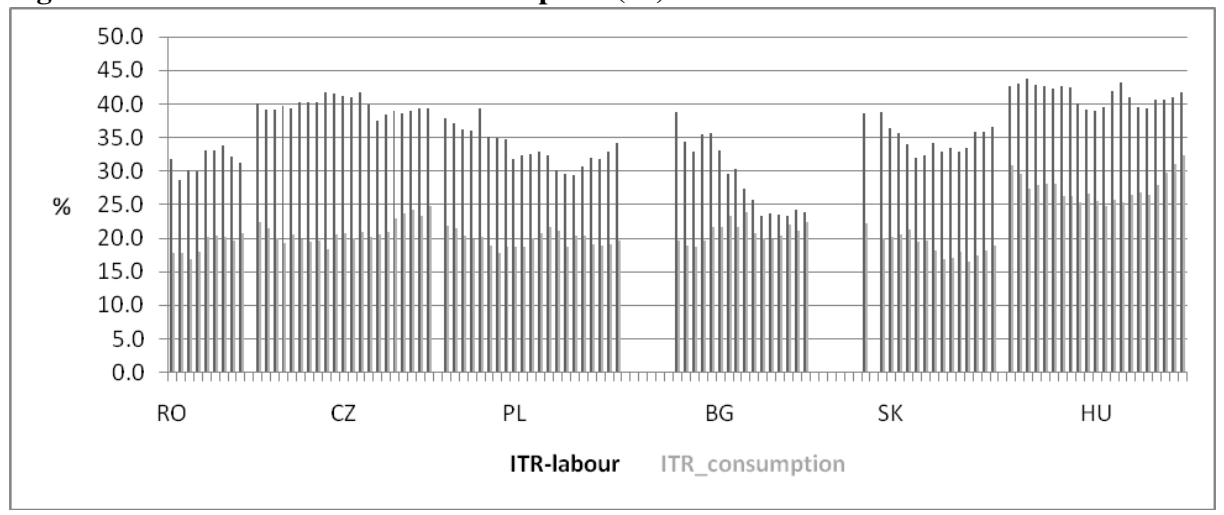

Source: Eurostat (2018)

\section{Methodology and data}

The effects of implicit tax rates on real convergence are studied using a set of unbalanced data, with 6 cross-sections ( 6 countries, i.e. Bulgaria, the Czech Republic Hungary, Poland, Romania and Slovakia) for 1995-2016, using a panel model approach. A panel model is used because it allows the control for individual heterogeneity; this model also gives more informative data, more variability, less collinearity among the variables and more efficiency (Baltagi, 2008). The study focuses on the above-mentioned countries because they belonged to the same political and economic block and shared a similar fate (Kovacs, 2013). Moreover, according to Farkas (2011), an independent CEE model of capitalism is eligible, considering the following three main aspects: lack of capital, weak civil society and a significant influence of the EU and other international organizations.

Nevertheless, all these countries have, lately, made considerable efforts to attract foreign capital and consolidate the domestic capital, have made steps to improve the quality of governance and of institutions, as well as improving the social capital.

Similar to Franks et al. (2018), three dependent variables for real convergence, i.e. GDP per capita, labour productivity and unemployment rate are considered to explore the relationship between implicit tax rates and real convergence. As interest variables, two main tax rates, i.e. implicit tax rates on labour and implicit tax rates on consumption, respectively are considered.

As aforementioned, the dependent variables are: i) GDP per capita $(\gamma)$, which refers to Gross Domestic Product per capita measured in PPS; ii) unemployment rate $(\rho)$, measured by the number of unemployed as percentage of total workforce (aged 15 to 64); iii) labour productivity $(\varphi)$, which refers to nominal labour productivity per person, measured as percentage of EU-28 total (based on million PPS, current prices).

The interest variables are: i) implicit tax rates on labour $(\lambda)$, calculated as the ratio of taxes on employed labour and the sum of compensation of employees, wage bill and payroll 
taxes; and ii) implicit tax rates on consumption $(\chi)$, determined as the ratio of taxes on consumption and final consumption expenditure of household on the economic territory. Since the main hypothesis considers that implicit tax rates impact real convergence variables, the basic functions have the following form:

$$
\begin{aligned}
& \gamma=f(\lambda, \chi), \\
& \rho=f(\lambda, \chi), \\
& \varphi=f(\lambda, \chi)
\end{aligned}
$$

where $\gamma$-GDP per capita, $\rho$ - unemployment rate, $\varphi$ - labour productivity and $\lambda, \chi-$ implicit tax rates on labour and consumption, respectively.

The basic OLS naive panel-models are as follows:

$$
\begin{aligned}
& \gamma_{i t}=\alpha+\beta_{0} \lambda_{i t}+\beta_{1} \chi_{i t}+\varepsilon_{i t} \\
& \rho_{i t}=\alpha+\beta_{0} \lambda_{i t}+\beta_{1} \chi_{i t}+\varepsilon_{i t} \\
& \varphi_{i t}=\alpha+\beta_{0} \lambda_{i t}+\beta_{1} \chi_{i t}+\varepsilon_{i t}
\end{aligned}
$$

where: $\alpha$-intercept, $\beta_{0,1}$ - slops of interest tax rates variables, $i$ - country, $t$ - time, and $\varepsilon_{i t}$ - the error term, which varies over both country, and time.

The effects of implicit tax rates variables are isolated by entering two types of control variables: one that relies on quantitative data and another one containing robustness variables (qualitative data). In this case, the extended linear models become:

$$
\begin{aligned}
& \gamma_{i t}=\alpha+\beta_{0} \lambda_{i t}+\beta_{1} \chi_{i t}+\sum_{k=1}^{n} \beta_{k} X_{k, i t}+\mu_{i}+\eta_{t}+\varepsilon_{i t} \\
& \rho_{i t}=\alpha+\beta_{0} \lambda_{i t}+\beta_{1} \chi_{i t}+\sum_{k=1}^{n} \beta_{k} X_{k, i t}+\mu_{i}+\eta_{t}+\varepsilon_{i t} \\
& \varphi_{i t}=\alpha+\beta_{0} \lambda_{i t}+\beta_{1} \chi_{i t}+\sum_{k=1}^{n} \beta_{k} X_{k, i t}+\mu_{i}+\eta_{t}+\varepsilon_{i t}
\end{aligned}
$$

where $\alpha$-intercept, $\beta_{0,1}$ - coefficients of implicit tax rates variables, $\beta_{k}-$ coefficient of control independent variable $k$ by $n$ type, $X$ - control independent variables, $\mu_{i}-$ stands for country fixed effects, $\eta_{t}$ - time-specific effect that controls for unaccounted common time-varying factors, $i$ - country, $t-$ time, $\varepsilon_{i t}-$ the error term.

However, it is notable that a significant collinearity between implicit tax rates (ITR) on labour and implicit tax rates on consumption was found; this makes equations (7), (8) and (9) difficult to estimate. Having this in mind, these equations for both ITR on labour and ITR on consumption separately are estimated, as follows: 


$$
\begin{aligned}
& \gamma_{i t}=\alpha+\beta_{0} \lambda_{i t}+\sum_{k=1}^{n} \beta_{k} X_{k, i t}+\mu_{i}+\eta_{t}+\varepsilon_{i t} \\
& \gamma_{i t}=\alpha+\beta_{0} \chi_{i t}+\sum_{k=1}^{n} \beta_{k} X_{k, i t}+\mu_{i}+\eta_{t}+\varepsilon_{i t} \\
& \rho_{i t}=\alpha+\beta_{0} \lambda_{i t}+\sum_{k=1}^{n} \beta_{k} X_{k, i t}+\mu_{i}+\eta_{t}+\varepsilon_{i t} \\
& \rho_{i t}=\alpha+\beta_{0} \chi_{i t}+\sum_{k=1}^{n} \beta_{k} X_{k, i t}+\mu_{i}+\eta_{t}+\varepsilon_{i t} \\
& \varphi_{i t}=\alpha+\beta_{0} \lambda_{i t}+\sum_{k=1}^{n} \beta_{k} X_{k, i t}+\mu_{i}+\eta_{t}+\varepsilon_{i t} \\
& \varphi_{i t}=\alpha+\beta_{0} \chi_{i t}+\sum_{k=1}^{n} \beta_{k} X_{k, i t}+\mu_{i}+\eta_{t}+\varepsilon_{i t}
\end{aligned}
$$

The first set of control variables includes: gross fixed capital formation (investments), foreign direct investment, economy openness, inflation, net earnings, labour force, GDP and population. Gross fixed capital formation consists of resident producers' investments, deducting disposals in fixed assets during a given period as a percentage of GDP. The second control variable, net FDI, illustrates the net inflows (new investment inflows less disinvestment) in the reporting economy from foreign investors, and is divided by GDP. Economy openness is measured by the exports of goods and services (\% of GDP), which represent the value of all goods and other market services provided to the rest of the world, while inflation shows the rate of price change in the economy as a whole. The fifth control variable, net earnings, refers to the amount of euro that a single person, without children, is earning (at $100 \%$ of the average wage). Labour force includes the population aged 15+, who supply labour for the production of goods and services during a specified period. It includes individuals who are currently employed and those who are unemployed but are seeking jobs as well as first-time job-seekers. GDP at purchaser's prices is the sum of gross value added by all resident producers in the economy plus any product taxes and minus any subsidies not included in the value of the products. It is calculated without making deductions for depreciation of fabricated assets or for depletion and degradation of natural resources. Data are in constant 2010 U.S. dollars. Population refers to the number of inhabitants in a country.

The variables for robustness refer to: property rights, freedom from corruption, political stability and absence of violence/terrorism, rule of law and education. Property rights explain the ability of individuals to accumulate private property secured by clear laws that are fully enforced by the state (the score 100 means secure property rights, while a level of 0 suggests a weak protection of these rights). Freedom from corruption shows the intensity of corruption (the score 100 means low corruption, while a level of 0 indicates a very corrupt government). Political stability is included in the six dimensions of governance of 
The Worldwide Governance Indicators (WGI) project: "political stability and absence of violence/terrorism" measures the likelihood that the government will be destabilized by unconstitutional or violent means, including terrorism (estimate gives the country's score on the aggregate indicator, in units of a standard normal distribution, i.e. ranging from approximately -2.5 to 2.5 ); rule of law shows the extent to which agents have confidence in and abide by the rules of society, including the quality of contract enforcement and property rights, the police, and the courts, as well as the likelihood of crime and violence (percentile rank indicates the country's rank among all countries covered by the aggregate indicator, with 0 corresponding to lowest rank, and 100 to highest rank). Finally, education refers to the number of graduates of upper secondary, post-secondary non-tertiary and tertiary education (levels 3-8), as percentage of total population aged 15 to 64 . The source of data for all the variables is presented in Appendix (Table A).

The three dependent variables were considered and tested separately, certain control variables being selected for each:

* when testing GDP per capita as dependent variable, control variables, which have a consistent impact on economic development, were chosen (Petrakos et al., 2007): gross fixed capital formation (investments), foreign direct investment, economy openness, inflation, property rights, freedom from corruption, political stability and absence of violence/terrorism, and education.

* when testing labour productivity, a different set of control variables were selected (Kazaz et al., 2016): net earnings, labour force, net foreign direct investment, education, freedom from corruption, political stability and absence of violence/terrorism.

* when testing unemployment rate, GDP, foreign direct investment, economy openness, inflation, population, education, political stability and absence of violence/terrorism, and rule of law were used as control variables. The decision regarding the aforementioned variables is in accordance with the findings of (Startiene et al., 2009), (Enea et al., 2009) and (Totan et al., 2013).

The following stage of the analysis consists in testing the variables' stationarity. The eligibility conditions for a time series to be stationary are as follow: on one hand, the average of the time series is constant or, the observations should fluctuate around the average; on the other hand, the series' variance is constant. In other words, the series is stationary (doesn't have a unit root) if a shock over the series is temporary (it is absorbed in time). If a series is not stationary, it can become stationary through differentiation. In this case, the order of integration of the series is the number of successive differentiations required to obtain a stationary series.

Regarding the considered variables, the level stationarity of the series was first tested using a set of stationarity tests (Levin, Lin \& Chu t*; Im, Pesaran and Shin W-stat; ADF - Fisher Chi-square; PP - Fisher Chi-square). The results ${ }^{3}$ clearly show that the series are not stationary. Therefore, a first differentiation of the series was run and the results indicate that the first order integrated series are stationary (there's no unit root). The tests

\footnotetext{
${ }^{3}$ The results regarding the stationarity tests are available at request.
} 
provide information about the outcomes, critical values for each level of relevance (1\%, $5 \%$ or $10 \%$ ) and the probability "p" associated to the test's result. For every test, if the test value is greater than the critical one, the null hypothesis is accepted, and the series has a unit root (is non-stationary). Given these findings, regressions were performed using the stationary series (first order integrated).

In the panel-model approach, the model may have heterogeneity in the data. As the investigated sample is unbalanced, this property in the case of cross-section fixed-effects model and period fixed-effects model was tested. The random effects panel-models are not consistent under unbalanced data-set. In this demarche, F-test and Chi-square test allow to choose between pooled model and fixed-effects model.

The next section highlights the main empirical results of the explored functions, performing several econometric scenarios (models 1-4), as Tables B-G in Appendix illustrate.

\section{Results}

After statistically testing for ITR on labour - GDP per capita nexus, (Appendix, Table B), the results show that the interest variable appears insignificant in all four models. When looking at ITR on consumption (Appendix, Table C), they have a negative impact on GDP per capita, and the coefficients are statistically significant (except the first model, i.e. the "naïve" regression).

Further on, the hypothesis tests are initiated to choose between pooled model and fixedeffects model. The values of F-test and Chi-square test for cross-section and period fixed-effects reveal that the cross-section - period fixed-effects model is preferred to the OLS estimations for both ITR on labour and ITR on consumption (see Appendix, Tables B and C).

According to the OLS - fixed effects model (4), ITR on labour have a statistically insignificant impact on GDP per capita, while ITR on consumption are significant, with negative effect on GDP per capita. Two control variables are conclusive: gross fixed capital formation and political stability, with a positive impact on GDP per capita. As for the rest of the control variables, they have no statistical significance.

Regarding the ITR on labour - labour productivity nexus, the results achieved after the statistical testing, as (Appendix, Table D) reveals, illustrate that the interest variable appears insignificant in all four models. As for ITR on consumption (Appendix, Table E), they have a negative impact on labour productivity, and the coefficients are statistically significant (except the first model).

Similar to the previous two cases, the hypothesis tests were initiated to choose between the pooled model and fixed-effects model. The values of F-test and Chi-square test for cross-section and period fixed-effects reveal that the cross-section - period fixed-effects model is preferred to the OLS estimations for both ITR on labour and ITR on consumption (see Appendix, Tables D and E).

Finally, when testing the ITR on labour - unemployment rate nexus, the results after the statistical testing, as Table $\mathrm{F}$ in Appendix reveals that the interest variable appears insignificant in three of the four models (model no. 2 shows significance). As for ITR on 
consumption (Appendix, Table G), they have a negative impact on unemployment, and the coefficients are statistically significant, except for model (3).

Further on, the hypothesis tests to choose between pooled model and fixed-effects model are initiated. The values of F-test and Chi-square test for cross-section and period fixedeffects reveal that the cross-section - period fixed-effects model is preferred to the OLS estimations for both ITR on labour and ITR on consumption (see Appendix, Tables F and $G)$.

To conclude, according to the OLS - fixed effects model (4), ITR on labour have a statistically insignificant impact on unemployment rate, while ITR on consumption are statistically significant, with negative effect on the dependent variable. Only one of the control variables is conclusive, i.e. education, with a positive impact. As for the rest of the control variables, they have no statistical significance.

\section{Conclusion}

Considering six CEE countries, the paper argues that there is a convergence club stance that can constitute a pillar of growth in the EU given their resilience to shocks and sustainable growth potential. The paper also examines the influence of implicit labour and consumption taxes on the selected real convergence indicators: i.e. GDP per capita, labour productivity and unemployment.

The conclusions are supported by the fact that in the aftermath of the crises, the entire group of countries followed a similar stable growth trend, by adopting the appropriate macroprudential policies (Donath et al., 2014). Nevertheless, there are significant differentials concerning the GDP per capita that are mainly explained by the level of exports, gross capital formation and FDI, which are among the most influential determinants according to the analysis. From this perspective, the gross capital formation and exports are the main driving forces. On the other hand, productivity is lower than the percentage of upper secondary education, except Slovakia and Hungary, where the statistics show a better correlation among these two indicators. The unemployment rate is decreasing in all six countries, but further discussion is necessary on the determinants of these trends, whether it is due to the relatively high demand or brain drain.

From the taxation point of view, the majority of models exhibit an insignificant impact of the ITR on labour and a negative influence of ITR on consumption on the GDP, productivity and unemployment.

As expected, the gross capital formation and political stability influence the GDP per capita, since the first is a prerequisite of productivity and exports, while the second confers credibility to the business environment.

Concerning the labour productivity, freedom from corruption has a positive impact since it grants fairness and equity on the labour market. The net earnings that are quite low in this group of countries as compared to the EU developed countries and the FDI at low percentage of the GDP do not seem to significantly influence productivity but, here, an extended argumentation on the determinants, drivers and structure of the FDI as well as of earnings is needed. 
The unemployment rate is significantly influenced only by education, the higher the number of educated labour, the smaller the unemployment rate. Nevertheless, corrections are needed to enhance competition mainly in the product market and to prevent profit mark ups. Moreover, the flexibility of the wages is necessary to prevent the reallocation of labour to fast growing sectors and unemployment in key sectors.

Though the ITR on labour is quite low, it does not significantly influence the convergence indicators, whereas the ITR on consumption has a negative effect, which raises concerns for the erosion of GDP per capita and productivity as fundamentals of savings, investment and growth. Whereas taxing consumption is highly regarded as an important public revenue source, it does not support sustainable growth. Therefore, efforts are needed to shift consumption-based growth to production and export-based growth.

Corroborated with business policies enhancement and increase of earnings and profits, taxation lays the foundation for an enlargement of the direct tax base and public finance sustainability.

The analysis shows that the Visegrad countries are better harmonised from the convergence perspective, but the extended group, including Romania and Bulgaria have a catching up potential, proving that there is a $\beta$-convergence stance. As the analysis and the statistics show, gross capital formation and export potential can be the main convergence drivers for GDP per capita, productivity and net earnings increase. Moreover, the determinants of FDI should be identified to encourage inflows that can complement the domestic capital and contribute to productivity transfer. Since the human capital is the most important resource, investments in education should become a priority, as a prerequisite of a higher productivity and employment.

\section{References}

Baltagi, B. H. (2008). Econometric Analysis of Panel Data (3rd ed.). Chichester: John Wiley \& Sons Ltd.

Baumol, W. J. (1986). Productivity Growth, Convergence, and Welfare: What the Longrun Data Show. American Economic Review, 76(1), 1072-1085.

Barro, R. J., Sala-I-Martin, X. (1992). Convergence. Journal of Political Economy, 100(2), 223-250.

Bovenberg, A. L. (2003). Tax policy and labour market performance. CentER Tilburg University, CESifo, and CEPR. Retrieved September 1, 2018, from https://pure.uvt.nl/ws/ portalfiles/portal/598587/90.pdf.

Blundell, R. (2014). How Responsive is the Labor Market to Tax Policy?. IZA World of Labour 2014. Retrieved July 5, 2018, from wol.iza.org.

Ceylan, R., Abiyev, V. (2016). An Examination of Convergence Hypothesis for EU 15 countries. International Review of Economics and Finance, 45, 96-105.

de Haan, J., Sturm, E., Volkerink, B. (2003). How to Measure the Tax Burden on Labour at the Macro-level?. Cesifo Working Paper 963.

Donath, L., Mihutescu Cerna, V., Oprea, I. (2014). Financial Cycles and Macroprudential Intervention in Selected Central and Eastern European Countries. Proceeding of the 15th 
International Conference on finance and banking 25 Years of Economic and Financial Transition in Central and Eastern Europe, 60-72. Retrieved October 3, 2018, from http://icfb.rs.opf.slu.cz/content/conference-proceedings-2015.

Enea Smarandache, I., Ciurlau, C.F. (2009). Components of the Unemployment Analysis in Contemporary Economies. Annals of the Constantin Brâncuşi University of Târgu Jiu, Economy Section, 1.

EU Commission (2005). Structures of the taxation systems in the European Union: 1995-2004, Report COM(2006) 3201.

Farkas, B. (2011). The Central and Eastern European Model of Capitalism. PostCommunist Economies, 23(1), 15-34.

Franks, J., Barkbu, B., Blavy, R., Oman, W., Schoelermann, H. (2018). Economic Convergence in the Euro Area: Coming Together or Drifting Apart?. IMF Working Paper, $\mathrm{WP} / 18 / 10$.

Heijmans, P., Acciari, P. (2004). Examination of the Macroeconomic Implicit Tax Rate on Labour derived by EU Commission. Retrieved September 10, 2018, from http://europa.eu.int/comm/taxation_customs/taxation/taxation.htm.

Inklaar, R., Diewert, W. E. (2016). Measuring Industry Productivity and Cross-Country Convergence. Journal of Econometric, 191, 426-433.

Jovančević, R., Globan, T., Recher, V. (2015). Does the Cohesion Policy Decrease Economic Inequalities in the European Union?. Zagreb International Review of Economics \& Business, 18(2), 1-20.

Kazaz, A., Ulubeyl, S., Acikara, T., Bayram, E. R. (2016). Factors Affecting Labour Productivity: Perspectives of Craft Workers. Procedia Engineering, 164, 28-34.

Kovacs, A. (2013). Crisis Management Similarities and Differences in the Newly Accessed Central and Eastern European Countries. In Beáta Farkas (Ed.) The Aftermath of the Global Crisis in the European Union. Cambridge: Cambridge Scholars Publishing.

Lee, Y., Gordon, R. (2005). Tax structure and economic growth. Journal of Public Economics, 89, 1027-1043.

Martín, C., Velázques, F., Funck, B. (2001). European Integration and Income Convergence: Lessons For Central And Eastern European Countries. World Bank Technical Paper, 514. Retrieved September 1, 2018, from https://openknowledge.worldbank.org/bitstream/handle/10986/13968/multi0page.pdf?sequence $=1$.

Mlynarzewska-Borowiec, I. (2018). Determinants of the Real Convergence Process in the European Union - a panel analysis for 2004-2015. Argumenta oeconomica, 40, 345-363. Onaran, O., Boesch, V., Leibrecht, M. (2012). How does Globalization affect the Implicit Tax Rates on Labour Income, Capital Income and Consumption in the EU?. Economic Inquiry, 50(4), 880-904.

Petrakos, G., Arvanitidis, P., Pavleas, S. (2007). Determinants of Economic Growth: The Experts' View. DYNREG Working Papers.

Rodrick, D. (2002). Institutions, Integration, and Geography: In Search of the Deep Determinants of Economic Growth, Harvard University. Retrieved October 4, 2018, from http://www.tinyurl.com/mdm5yks. 
Simionescu, M. (2015). About Regional Convergence Clubs in the European Union. Proceedings of Rijeka Faculty of Economics, 33(1), 67-80.

Soric, P. (2017). Real Convergence of EU Economies: Do Structural Breaks Matter? Ekonomický časopis, 65(8), 691-714.

Startiene, G., Remeikiene, R. (2009). The Influence of Demographical Factors on the Interaction between Entrepreneurship and Unemployment. Inzinerine EkonomikaEngineering Economics, 4.

Totan, L. S., Popescu, B. B., Cristache, S. E. (2013). Impactul somajului asupra creşterii economice din România, în perioada de criză. Romanian Statistical Review, 6.

Zdražil, P., Appolova, P. (2016). Growth Disparities among Regions of the Visegrad Group Countries: An evidence of their Extent and Nature. E \& M Ekonomie a Management, 19(2), $37-54$.

Workie, T. M. (2004). Measuring Income per capita Disparities across Countries Using a Panel Data Approach. Ekonomický časopis, 52(7), 801-819. 


\section{Appendix}

Table A: Source of data

\begin{tabular}{|l|l|}
\hline \multicolumn{1}{|c|}{ Variable } & \multicolumn{1}{c|}{ Source } \\
\hline Unemployment rate & World Bank online database (2018) \\
\hline Gross Domestic Product & World Bank online database (2018) \\
\hline Gross Domestic Product per capita & Eurostat online database \\
\hline Labour productivity & Eurostat online database \\
\hline Net earning & Eurostat online database \\
\hline Labour force & World Bank online database (2018) \\
\hline Population & Eurostat online database \\
\hline Gross fixed capital formation as \% of GDP & World Bank online database (2018) \\
\hline Exports of goods and services as \% of GDP & World Bank online database (2018) \\
\hline Net FDI as \% of GDP & World Bank online database (2018) \\
\hline Inflation rate & World Bank online database (2018) \\
\hline Freedom from corruption & The Heritage Foundation online data-base (2018) \\
\hline Property rights & The Heritage Foundation online data-base (2018) \\
\hline $\begin{array}{l}\text { Political stability and absence of } \\
\text { violence/terrorism }\end{array}$ & $\begin{array}{l}\text { The Worldwide Governance Indicators, 2018 } \\
\text { Update }\end{array}$ \\
\hline Rule of law & $\begin{array}{l}\text { The Worldwide Governance Indicators, 2018 } \\
\text { Update }\end{array}$ \\
\hline Education & Eurostat online database \\
\hline
\end{tabular}


Table B: Empirical results of panel regressions (ITR on labour - GDP per capita)

\begin{tabular}{|c|c|c|c|c|}
\hline \multicolumn{5}{|c|}{ Dependent variable: In GDP per capita } \\
\hline \multirow{2}{*}{$\begin{array}{l}\text { Independent } \\
\text { variables }\end{array}$} & \multicolumn{4}{|c|}{ Model } \\
\hline & (1) & (2) & (3) & (4) \\
\hline constant & $\begin{array}{c}0.054060 * * * \\
(13.68722)\end{array}$ & $\begin{array}{c}0.050654 * * * \\
(13.57063)\end{array}$ & $\begin{array}{c}0.044323 * * * \\
(7.451730)\end{array}$ & $\begin{array}{c}0.051197 * * * \\
(11.07341)\end{array}$ \\
\hline ITR on labour & $\begin{array}{c}-0.000267 \\
(-0.099449)\end{array}$ & $\begin{array}{c}-0.001157 \\
(-0.531753)\end{array}$ & $\begin{array}{c}-0.000709 \\
(-0.255699)\end{array}$ & $\begin{array}{c}0.000949 \\
(0.425317)\end{array}$ \\
\hline $\begin{array}{l}\text { gross fixed capital } \\
\text { formation as } \% \text { of GDP }\end{array}$ & & $\begin{array}{c}0.010116^{* * * *} \\
(7.215814)\end{array}$ & $\begin{array}{c}0.010166 * * * \\
(5.642097)\end{array}$ & $\begin{array}{l}0.004193 * * \\
(2.535798)\end{array}$ \\
\hline net FDI as $\%$ of GDP & & $\begin{array}{l}0.000804 * \\
(1.868586) \\
\end{array}$ & $\begin{array}{c}0.000668 \\
(1.378082) \\
\end{array}$ & $\begin{array}{c}-0.000178 \\
(-0.471777) \\
\end{array}$ \\
\hline inflation rate $(\%)$ & & $\begin{array}{c}-0.000588 \\
(-0.566179)\end{array}$ & $\begin{array}{c}-0.000403 \\
(-0.215770)\end{array}$ & $\begin{array}{c}0.001833 \\
(1.232545)\end{array}$ \\
\hline $\begin{array}{l}\text { exports of goods and } \\
\text { services as } \% \text { of GDP }\end{array}$ & & $\begin{array}{l}0.001495^{*} \\
(1.817076)\end{array}$ & $\begin{array}{c}0.002408 * * \\
(2.178382)\end{array}$ & $\begin{array}{c}-0.000631 \\
(-0.574221)\end{array}$ \\
\hline education & & & $\begin{array}{c}0.002517 \\
(0.491633)\end{array}$ & $\begin{array}{c}0.004509 \\
(1.049560)\end{array}$ \\
\hline property rights & & & $\begin{array}{c}-0.000314 \\
(-0.296678)\end{array}$ & $\begin{array}{c}0.000984 \\
(1.160071)\end{array}$ \\
\hline $\begin{array}{l}\text { freedom from } \\
\text { corruption }\end{array}$ & & & $\begin{array}{c}0.001701 \\
(1.110678)\end{array}$ & $\begin{array}{c}0.001436 \\
(1.000915)\end{array}$ \\
\hline $\begin{array}{l}\text { political stability and } \\
\text { absence of } \\
\text { violence/terrorism }\end{array}$ & & & $\begin{array}{c}0.028526 \\
(1.055195)\end{array}$ & $\begin{array}{c}0.058371 * * \\
(2.058949)\end{array}$ \\
\hline Type of estimation & OLS & OLS & OLS & $\begin{array}{c}\text { OLS - } \\
\text { FE:CS, PE }\end{array}$ \\
\hline \multicolumn{5}{|c|}{ Model summary } \\
\hline R squared & 0.000098 & 0.406943 & 0.457177 & 0.807484 \\
\hline F-test for fixed effects & & & & $\begin{array}{c}5.458867 \\
(0.0000) \\
\end{array}$ \\
\hline Chi-square & & & & $\begin{array}{c}80.855030 \\
(0.0000)\end{array}$ \\
\hline
\end{tabular}

a. (...) denotes the $t$-stat; for F-test for fixed effects, Chi-square, (...) denotes the probability;

b. FE:CS, PE denotes cross-section and period fixed effects;

c. $* * *, * *$ and $*$ denote significance at 1,5 and $10 \%$ level of significance, respectively. 
DANUBE: Law, Economics and Social Issues Review, 10 (1), 67-89

DOI: 10.2478/danb-2019-0004

Table C: Empirical results of panel regressions (ITR on consumption - GDP per capita)

\begin{tabular}{|c|c|c|c|c|}
\hline \multicolumn{5}{|c|}{ Dependent variable: In GDP per capita } \\
\hline \multirow{2}{*}{$\begin{array}{l}\text { Independent } \\
\text { variables }\end{array}$} & \multicolumn{4}{|c|}{ Model } \\
\hline & (1) & (2) & (3) & (4) \\
\hline constant & $\begin{array}{c}0.054064 * * * \\
(13.82704)\end{array}$ & $\begin{array}{c}0.050927 * * * \\
(14.10594)\end{array}$ & $\begin{array}{c}0.046495 * * * \\
(7.882739)\end{array}$ & $\begin{array}{c}0.054804 * * * \\
(12.38504)\end{array}$ \\
\hline ITR on labour & $\begin{array}{c}0.000785 \\
(0.223965)\end{array}$ & $\begin{array}{c}-0.006572 * * \\
(-2.296827)\end{array}$ & $\begin{array}{l}-0.007232 * \\
(-1.936511)\end{array}$ & $\begin{array}{l}-0.008363 * * \\
(-3.047543)\end{array}$ \\
\hline $\begin{array}{l}\text { gross fixed capital } \\
\text { formation as } \% \text { of GDP }\end{array}$ & & $\begin{array}{c}0.011137 * * * \\
(7.791252)\end{array}$ & $\begin{array}{c}0.011561 * * * \\
(6.096899)\end{array}$ & $\begin{array}{c}0.005671 * * * \\
(3.546595)\end{array}$ \\
\hline net FDI as $\%$ of GDP & & $\begin{array}{c}0.000653 \\
(1.584466) \\
\end{array}$ & $\begin{array}{c}0.000526 \\
(1.138521) \\
\end{array}$ & $\begin{array}{c}-0.000257 \\
(-0.738284) \\
\end{array}$ \\
\hline inflation rate $(\%)$ & & $\begin{array}{c}-0.000518 \\
(-0.511214)\end{array}$ & $\begin{array}{c}-0.000508 \\
(-0.278744)\end{array}$ & $\begin{array}{c}0.001853 \\
(1.361434)\end{array}$ \\
\hline $\begin{array}{l}\text { exports of goods and } \\
\text { services as } \% \text { of GDP }\end{array}$ & & $\begin{array}{c}0.001758 \\
(2.167463)\end{array}$ & $\begin{array}{c}0.002776 * * \\
(2.539826)\end{array}$ & $\begin{array}{c}-0.000518 \\
(-0.511687)\end{array}$ \\
\hline education & & & $\begin{array}{c}0.001057 \\
(0.211763)\end{array}$ & $\begin{array}{c}0.001713 \\
(0.430490)\end{array}$ \\
\hline property rights & & & $\begin{array}{c}-0.000389 \\
(-0.376706)\end{array}$ & $\begin{array}{c}0.001037 \\
(1.330365)\end{array}$ \\
\hline $\begin{array}{l}\text { freedom from } \\
\text { corruption }\end{array}$ & & & $\begin{array}{c}0.001452 \\
(0.970902)\end{array}$ & $\begin{array}{c}0.001294 \\
(0.984987)\end{array}$ \\
\hline $\begin{array}{l}\text { political stability and } \\
\text { absence of } \\
\text { violence/terrorism }\end{array}$ & & & $\begin{array}{c}0.027440 \\
(1.042311)\end{array}$ & $\begin{array}{l}0.059590 * * \\
(2.316620)\end{array}$ \\
\hline Type of estimation & OLS & OLS & OLS & $\begin{array}{c}\text { OLS - } \\
\text { FE:CS, PE }\end{array}$ \\
\hline \multicolumn{5}{|c|}{ Model summary } \\
\hline R squared & 0.000496 & 0.435893 & 0.485053 & 0.836564 \\
\hline F-test for fixed effects & & & & $\begin{array}{c}6.452260 \\
(0.0000)\end{array}$ \\
\hline Chi-square & & & & $\begin{array}{c}89.516040 \\
(0.0000)\end{array}$ \\
\hline
\end{tabular}

a. (...) denotes the $t$-stat; for F-test for fixed effects, Chi-square, (...) denotes the probability;

b. FE:CS, PE denotes cross-section and period fixed effects;

c. $* * * * *$ and $*$ denote significance at 1,5 and $10 \%$ level of significance, respectively. 
Table D: Empirical results of panel regressions (ITR on labour - labour F-productivity)

\begin{tabular}{|c|c|c|c|c|}
\hline \multicolumn{5}{|c|}{ Dependent variable: labour productivity } \\
\hline \multirow{2}{*}{$\begin{array}{l}\text { Independent } \\
\text { variables }\end{array}$} & \multicolumn{4}{|c|}{ Model } \\
\hline & (1) & (2) & (3) & (4) \\
\hline constant & $\begin{array}{c}1.176472 * * * \\
(7.073991)\end{array}$ & $\begin{array}{c}1.159138 * * * \\
(4.959167)\end{array}$ & $\begin{array}{c}0.962594 * * * \\
(3.121642)\end{array}$ & $\begin{array}{c}1.356994 * * * \\
(3.751921)\end{array}$ \\
\hline ITR on labour & $\begin{array}{c}-0.127108 \\
(-1.068189)\end{array}$ & $\begin{array}{c}-0.073326 \\
(-0.582976)\end{array}$ & $\begin{array}{c}-0.082631 \\
(-0.591717)\end{array}$ & $\begin{array}{c}-0.067955 \\
(-0.466156)\end{array}$ \\
\hline ln net earnings & & $\begin{array}{c}1.805922 \\
(0.780980)\end{array}$ & $\begin{array}{c}1.361713 \\
(0.506566)\end{array}$ & $\begin{array}{l}-6.952759 * \\
(-1.873369)\end{array}$ \\
\hline net FDI as $\%$ of GDP & & $\begin{array}{c}-0.017343 \\
(-0.794479)\end{array}$ & $\begin{array}{c}-0.017906 \\
(-0.781938)\end{array}$ & $\begin{array}{l}-0.045757 * \\
(-1.848574)\end{array}$ \\
\hline ln work force & & $\begin{array}{c}-22.09199 * * \\
(-2.187657)\end{array}$ & $\begin{array}{c}-23.63137 \\
(-1.527044)\end{array}$ & $\begin{array}{c}-11.62846 \\
(-0.691677)\end{array}$ \\
\hline education & & & $\begin{array}{c}0.230587 \\
(0.911089) \\
\end{array}$ & $\begin{array}{c}0.331204 \\
(1.178688) \\
\end{array}$ \\
\hline $\begin{array}{l}\text { freedom from } \\
\text { corruption }\end{array}$ & & & $\begin{array}{c}0.087352 \\
(1.225601)\end{array}$ & $\begin{array}{l}0.168982 * \\
(1.794475)\end{array}$ \\
\hline $\begin{array}{l}\text { political stability and } \\
\text { absence of } \\
\text { violence/terrorism }\end{array}$ & & & $\begin{array}{c}0.160089 \\
(0.120571)\end{array}$ & $\begin{array}{c}0.240086 \\
(0.134896)\end{array}$ \\
\hline Type of estimation & OLS & OLS & OLS & $\begin{array}{c}\text { OLS - } \\
\text { FE:CS, PE }\end{array}$ \\
\hline \multicolumn{5}{|c|}{ Model summary } \\
\hline R squared & 0.011746 & 0.076357 & 0.085215 & 0.432698 \\
\hline F-test for fixed effects & & & & $\begin{array}{c}1.909613 \\
(0.0377)\end{array}$ \\
\hline Chi-square & & & & $\begin{array}{c}37.268137 \\
(0.0031)\end{array}$ \\
\hline
\end{tabular}

a. (...) denotes the $t$-stat; for F-test for fixed effects, Chi-square, (...) denotes the probability;

b. FE:CS, PE denotes cross-section and period fixed effects;

c. $* * * * *$ and $*$ denote significance at 1,5 and $10 \%$ level of significance, respectively. 
Table E: Empirical results of panel regressions (ITR on consumption - labour productivity)

\begin{tabular}{|c|c|c|c|c|}
\hline \multicolumn{5}{|c|}{ Dependent variable: labour productivity } \\
\hline \multirow{2}{*}{$\begin{array}{l}\text { Independent } \\
\text { variables }\end{array}$} & \multicolumn{4}{|c|}{ Model } \\
\hline & (1) & (2) & (3) & (4) \\
\hline constant & $\begin{array}{c}1.228154 * * * \\
(7.495786)\end{array}$ & $\begin{array}{c}1.203238 * * * \\
(5.312363)\end{array}$ & $\begin{array}{c}1.016231 * * * \\
(3.374199)\end{array}$ & $\begin{array}{c}1.475073 * * * \\
(4.132826)\end{array}$ \\
\hline ITR on consumption & $\begin{array}{c}-0.238745 \\
(-1.643091)\end{array}$ & $\begin{array}{c}-0.375213 * * \\
(-2.491453)\end{array}$ & $\begin{array}{c}-0.342861 * * \\
(-2.006942)\end{array}$ & $\begin{array}{l}-0.334442 * \\
(-1.857621)\end{array}$ \\
\hline ln net earnings & & $\begin{array}{c}2.359980 \\
(1.064905) \\
\end{array}$ & $\begin{array}{c}2.644713 \\
(1.004505) \\
\end{array}$ & $\begin{array}{l}-6.514668 * \\
(-1.833971) \\
\end{array}$ \\
\hline net FDI as $\%$ of GDP & & $\begin{array}{c}-0.022206 \\
(-1.089116)\end{array}$ & $\begin{array}{c}-0.023117 \\
(-1.080595) \\
\end{array}$ & $\begin{array}{c}-0.054292 * * \\
(-2.235595)\end{array}$ \\
\hline ln work force & & $\begin{array}{c}-21.60831 * * \\
(-2.214106)\end{array}$ & $\begin{array}{c}-19.99538 \\
(-1.319981)\end{array}$ & $\begin{array}{c}-6.263873 \\
(-0.379454)\end{array}$ \\
\hline education & & & $\begin{array}{c}0.185409 \\
(0.752895)\end{array}$ & $\begin{array}{c}0.251259 \\
(0.916263)\end{array}$ \\
\hline $\begin{array}{l}\text { freedom from } \\
\text { corruption }\end{array}$ & & & $\begin{array}{c}0.061421 \\
(0.869799)\end{array}$ & $\begin{array}{c}0.147285 \\
(1.619881)\end{array}$ \\
\hline $\begin{array}{l}\text { political stability and } \\
\text { absence of } \\
\text { violence/terrorism }\end{array}$ & & & $\begin{array}{c}-0.040470 \\
(-0.031196)\end{array}$ & $\begin{array}{c}0.004003 \\
(0.002319)\end{array}$ \\
\hline Type of estimation & OLS & OLS & OLS & $\begin{array}{c}\text { OLS - } \\
\text { FE:CS, PE }\end{array}$ \\
\hline \multicolumn{5}{|c|}{ Model summary } \\
\hline R squared & 0.027353 & 0.137109 & 0.130661 & 0.465192 \\
\hline F-test for fixed effects & & & & $\begin{array}{c}1.950139 \\
(0.0332) \\
\end{array}$ \\
\hline Chi-square & & & & $\begin{array}{c}37.894385 \\
(0.0025)\end{array}$ \\
\hline
\end{tabular}

a. (...) denotes the $t$-stat; for F-test for fixed effects, Chi-square, (...) denotes the probability;

b. FE:CS, PE denotes cross-section and period fixed effects;

c. $* * *, * *$ and $*$ denote significance at 1,5 and $10 \%$ level of significance, respectively. 
Table F: Empirical results of panel regressions (ITR on labour - unemployment rate)

\begin{tabular}{|c|c|c|c|c|}
\hline \multicolumn{5}{|c|}{ Dependent variable: unemployment rate } \\
\hline \multirow{2}{*}{$\begin{array}{l}\text { Independent } \\
\text { variables }\end{array}$} & \multicolumn{4}{|c|}{ Model } \\
\hline & (1) & (2) & (3) & (4) \\
\hline constant & $\begin{array}{l}-0.257278 * \\
(-1.668707) \\
\end{array}$ & $\begin{array}{c}0.333095 \\
(1.539914) \\
\end{array}$ & $\begin{array}{c}-0.102240 \\
(-0.427883) \\
\end{array}$ & $\begin{array}{c}-0.411162 \\
(-1.189058) \\
\end{array}$ \\
\hline ITR on labour & $\begin{array}{c}-0.163075 \\
(-1.555866)\end{array}$ & $\begin{array}{c}-0.204673 * * \\
(-2.129772)\end{array}$ & $\begin{array}{c}-0.064789 \\
(-0.658486)\end{array}$ & $\begin{array}{c}-0.033931 \\
(-0.331154)\end{array}$ \\
\hline $\ln$ GDP & & $\begin{array}{c}-25.33682 * * * \\
(-5.326337)\end{array}$ & $\begin{array}{c}-25.64988 \\
(-5.438959)\end{array}$ & $\begin{array}{c}-7.323033 \\
(-0.841516)\end{array}$ \\
\hline net FDI as $\%$ of GDP & & $\begin{array}{c}0.002219 \\
(0.116100)\end{array}$ & $\begin{array}{c}-0.019256 \\
(-1.090233)\end{array}$ & $\begin{array}{c}-0.003113 \\
(-0.180235)\end{array}$ \\
\hline inflation rate $(\%)$ & & $\begin{array}{l}-0.098132 * * \\
(-2.207950)\end{array}$ & $\begin{array}{l}-0.102411^{*} \\
(-1.738217)\end{array}$ & $\begin{array}{c}-0.016878 \\
(-0.258313)\end{array}$ \\
\hline ln population & & $\begin{array}{c}0.435765 \\
(0.017769) \\
\end{array}$ & $\begin{array}{c}5.794794 \\
(0.187307) \\
\end{array}$ & $\begin{array}{c}36.36977 \\
(0.676666) \\
\end{array}$ \\
\hline $\begin{array}{l}\text { exports of goods and } \\
\text { services as } \% \text { of GDP }\end{array}$ & & $\begin{array}{c}0.059091 \\
(1.644755)\end{array}$ & $\begin{array}{c}0.085049 * * \\
(2.346535)\end{array}$ & $\begin{array}{c}0.015900 \\
(0.325546)\end{array}$ \\
\hline education & & & $\begin{array}{c}0.387833 * * \\
(2.174890)\end{array}$ & $\begin{array}{c}0.405549 * * \\
(2.047153)\end{array}$ \\
\hline rule of law & & & $\begin{array}{l}4.292476^{*} \\
(1.943795)\end{array}$ & $\begin{array}{c}3.005146 \\
(1.260339) \\
\end{array}$ \\
\hline $\begin{array}{l}\text { political stability and } \\
\text { absence of } \\
\text { violence/terrorism }\end{array}$ & & & $\begin{array}{l}-1.739273^{*} \\
(-1.817936)\end{array}$ & $\begin{array}{c}-1.279629 \\
(-0.911227)\end{array}$ \\
\hline Type of estimation & OLS & OLS & OLS & $\begin{array}{c}\text { OLS - } \\
\text { FE:CS, PE }\end{array}$ \\
\hline \multicolumn{5}{|c|}{ Model summary } \\
\hline R squared & 0.023407 & 0.305287 & 0.455759 & 0.656699 \\
\hline F-test for fixed effects & & & & $\begin{array}{c}1.755958 \\
(0.0622) \\
\end{array}$ \\
\hline Chi-square & & & & $\begin{array}{l}35.941300 \\
(0.0047)\end{array}$ \\
\hline
\end{tabular}

a. (...) denotes the $t$-stat; for F-test for fixed effects, Chi-square, (. . .) denotes the probability;

b. FE:CS, PE denotes cross-section and period fixed effects;

c. ***, ** and $*$ denote significance at 1,5 and $10 \%$ level of significance, respectively. 
Table G: Empirical results of panel regressions (ITR on consumption - unemployment rate)

\begin{tabular}{|c|c|c|c|c|}
\hline \multicolumn{5}{|c|}{ Dependent variable: unemployment rate } \\
\hline \multirow{2}{*}{$\begin{array}{l}\text { Independent } \\
\text { variables }\end{array}$} & \multicolumn{4}{|c|}{ Model } \\
\hline & (1) & (2) & (3) & (4) \\
\hline constant & $\begin{array}{c}-0.203270 \\
(-1.335573)\end{array}$ & $\begin{array}{c}0.317717 \\
(1.460557)\end{array}$ & $\begin{array}{c}-0.068231 \\
(-0.286392)\end{array}$ & $\begin{array}{c}-0.167997 \\
(-0.475036)\end{array}$ \\
\hline ITR on consumption & $\begin{array}{l}-0.238274 * \\
(-1.747161)\end{array}$ & $\begin{array}{l}-0.220505^{*} \\
(-1.814057)\end{array}$ & $\begin{array}{c}-0.170775 \\
(-1.350053)\end{array}$ & $\begin{array}{c}-0.278673 * * \\
(-2.054811)\end{array}$ \\
\hline $\ln$ GDP & & $\begin{array}{c}-24.13938 * * * \\
(-5.081301)\end{array}$ & $\begin{array}{c}-25.34919 * * * \\
(-5.458046)\end{array}$ & $\begin{array}{c}-11.89827 \\
(-1.372951)\end{array}$ \\
\hline net FDI as $\%$ of GDP & & $\begin{array}{c}-0.010642 \\
(-0.569761)\end{array}$ & $\begin{array}{c}-0.061644 \\
(-1.487132)\end{array}$ & $\begin{array}{c}-0.008073 \\
(-0.487464)\end{array}$ \\
\hline inflation rate $(\%)$ & & $\begin{array}{l}-0.088427 * \\
(-1.963787)\end{array}$ & $\begin{array}{c}0.090828 * * \\
(2.508022)\end{array}$ & $\begin{array}{l}-0.009435 \\
(0.148657)\end{array}$ \\
\hline ln population & & $\begin{array}{c}-12.79587 \\
(-0.525513)\end{array}$ & $\begin{array}{c}-0.090236 \\
(-1.525150)\end{array}$ & $\begin{array}{c}17.77091 \\
(0.338661)\end{array}$ \\
\hline $\begin{array}{l}\text { exports of goods and } \\
\text { services as } \% \text { of GDP }\end{array}$ & & $\begin{array}{l}0.063940 * \\
(1.755782)\end{array}$ & $\begin{array}{c}-0.023657 \\
(-1.407357) \\
\end{array}$ & $\begin{array}{c}0.007034 \\
(0.149099)\end{array}$ \\
\hline education & & & $\begin{array}{l}0.371631 * * \\
(2.110251)\end{array}$ & $\begin{array}{l}0.358984 * \\
(1.896203)\end{array}$ \\
\hline rule of law & & & $\begin{array}{c}3.585494 \\
(1.585540)\end{array}$ & $\begin{array}{c}1.891728 \\
(0.802947)\end{array}$ \\
\hline $\begin{array}{l}\text { political stability and } \\
\text { absence of } \\
\text { violence/terrorism }\end{array}$ & & & $\begin{array}{l}-1.647705^{*} \\
(-1.734700)\end{array}$ & $\begin{array}{c}-0.895700 \\
(-0.661616)\end{array}$ \\
\hline Type of estimation & OLS & OLS & OLS & $\begin{array}{c}\text { OLS - } \\
\text { FE:CS, PE }\end{array}$ \\
\hline \multicolumn{5}{|c|}{ Model summary } \\
\hline $\mathrm{R}$ squared & 0.029337 & 0.296575 & 0.466586 & 0.682266 \\
\hline F-test for fixed effects & & & & $\begin{array}{c}2.036423 \\
(0.0261)\end{array}$ \\
\hline Chi-square & & & & $\begin{array}{c}40.410545 \\
(0.0011)\end{array}$ \\
\hline
\end{tabular}

a. (...) denotes the t-stat; for F-test for fixed effects, Chi-square, (. . .) denotes the probability;

b. FE:CS, PE denotes cross-section and period fixed effects;

c. ***, ** and $*$ denote significance at 1,5 and $10 \%$ level of significance, respectively. 